\title{
Ecopreneurship biology learning with local resources to raise high school student entrepreneurial interest
}

\author{
Yeni Suryaningsih, Ipin Aripin* \\ Pendidikan Biologi, Universitas Majalengka, Indonesia \\ *Coresponding Author: ipin_aripin@unma.ac.id
}

\begin{abstract}
This study has a goal to implement entrepreneurship-based biology learning with an awareness of the sustainability of resources and the environment known as ecopreneurship. Ecopreneurship biology learning activities with local resources are expected to foster student entrepreneurial interest. Quasiexperimental method with purposive sampling technique was used in this study with tenth-grade students at senior high school involved as the subjects. Ecopreneurship biology learning is carried out through five stages (introduction, concept formation, concept integration, concept application, and product exhibition. The research instruments were questionnaire on entrepreneurial interest, observation of learning activities, and assessment of students' ecopreneur products. The findings show that the student entrepreneurial interest increases by $9.58 \%$ (low category), $76 \%$ of students are actively involved during the learning process, and the average score of ecopreneur-product making is 3.1 (good category)
\end{abstract}

\author{
ARTICLE HISTORY \\ Received 2022-12-14 \\ Accepted 2022-01-30

\section{KEYWORDS} \\ Ecopreneurship \\ Biology Learning \\ Local Resources \\ Entrepreneurial Interest
}

\section{INTRODUCTION}

The high unemployment rate in Indonesia shows the low quality of human resources. Data from the Central Statistics Agency for 2020 show that the number of unemployed in Indonesia is more than 6 million people, most of whom are educated. It is necessary to address and find a solution to decrease the number of educated unemployed in the following years. Thus, an education system to provide students with knowledge and life skills in accordance with the environment and their needs is required. Students must have the necessary competencies following community development, such as character education, environmental awareness, constructivist learning approaches and methods, the balance of soft skills and hard skills, and entrepreneurship (Widiasworo, 2017).

Biology learning at the primary and secondary levels has set the basis for students to develop life skills through Life skills and Career-oriented learning with practicum, observation, and field study activities. Besides, biology learning accommodates concepts and knowledge about the relationship between living things and the environment (ecology) in the curriculum structure. If the scientific concepts of biology and knowledge about the environment are integrated with 
entrepreneurship learning, it can realize entrepreneurship-based biology learning that prioritizes environmental sustainability (ecopreneurship) (Isaak, 2002),(Kirkwood \& Walton, 2010).

Ecopreneurship comes from two words, ecological (eco) and entrepreneurship [(Beveridge \& Guy, 2005),(McEwen, 2013) meaning that an entrepreneur should consider environmental preservation and sustainability. Ecopreneur is an entrepreneur who cares about environmental issues or sustainability (Santini, 2017). Thus, in carrying out their business activities, they always consider their carrying capacity of the environment and try to minimize the impact of their activities on the environment. Ecopreneurship involves three main dimensions, namely society and social, economy, and ecology/environment (Galkina \& Hultman, 2016).

Ecopreneurship biology learning according to several studies can increase student entrepreneurial interest (Fitriah, 2012; Suryaningsih \& Aripin, 2020) build ecopreneurship (Martini et al., 2018) and instill a concern for sustainable development (Solaja, 2017). Inserting ecopreneurship in learning, especially in biology, is an alternative for teachers to develop entrepreneurship and concern for environmental sustainability in one learning. Ecopreneurship in biology learning is applied through contextual learning, namely biology learning associated with real objects. Students will be directed to make a product using local resources to be packaged creatively so that it has a high selling value.

Ecopreneurship-based learning aims to motivate students to have entrepreneurial interests (Fitriah, 2012), build ecopreneurship (Martini et al., 2018) instill a concern for sustainable development (Solaja, 2017), as well as concern for environmental sustainability (McEwen, 2013). With this learning, classroom learning will be more enjoyable and allow students to optimize their potential to explore their ideas in developing a product with local resources. When students are accustomed to such learning conditions, they may grow a high ecopreneurial interest.

Based on the previous theoretical studies and research on the relationship between entrepreneurship and the environment by (Holcombe, 1999), (Isaak, 2002), (Beveridge \& Guy, 2005), (Santini, 2017), entrepreneurship and the environment are contradictory where entrepreneurship (business) on a large scale has caused a lot of environmental damage; however, there is now a collective awareness of the importance of environmental sustainability among entrepreneurs so that they operate their business considering the environmental sustainability known as ecopreneurship or green entrepreneur.

Instilling the value of ecopreneurship by making products with local resources is expected to create prospective entrepreneurs who are creative and have a concern for environmental sustainability to avoid environmental exploitation for profits.

\section{METHODS}

A quasi-experiment method was applied because it directly tests the effect of one variable on the others and the causal-relationship hypothesis. Purposive sampling, a sampling technique tailored to the objectives of the study, was used. The sample of this study was the tenth-grade students of SMA Prakarya totaling 30 students. The data were collected through a literacy test for environmental knowledge, entrepreneurial interest questionnaire, and questionnaire on responses to learning. The data were then analyzed qualitatively and quantitatively using SPSS 24 for Windows. 


\section{RESULTS AND DISCUSSION}

Ecopreneurship-based biology learning with local resources is carried out in 5 stages (preliminary, concept formation, concept integration, concept application, and product exhibition). The phases of this research are as seen figure 1.

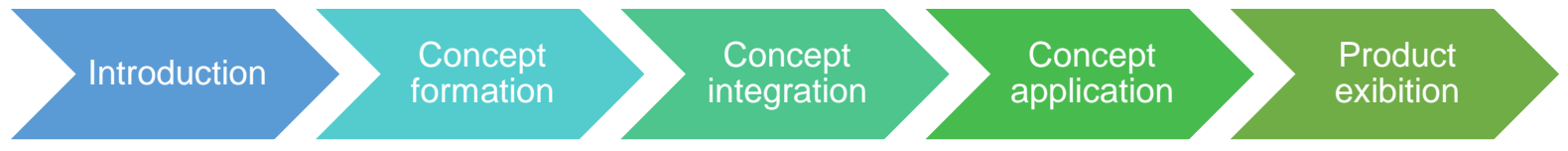

Figure 1. The Process of Ecopreneurship Biology Learning With Local Resources

The sequence of phases presented in Figure 1 is further explained as seen table 1.

Table 1. Phases of Ecopreneurship Biology Learning with Local Resources

\begin{tabular}{|c|c|c|}
\hline Phase & Activity & Goal \\
\hline Introduction & Group formation and apperception & $\begin{array}{l}\text { Building initial } \\
\text { perception }\end{array}$ \\
\hline Concept formation & $\begin{array}{l}\text { Concept assessment in the form of the } \\
\text { ecopreneur-based learning module }\end{array}$ & $\begin{array}{l}\text { Constructing students' } \\
\text { concept mastery }\end{array}$ \\
\hline Concept integration & $\begin{array}{l}\text { Developing ecopreneur ideas based on } \\
\text { the concepts learned }\end{array}$ & $\begin{array}{l}\text { Developing ideas into } \\
\text { product designs }\end{array}$ \\
\hline Concept application & $\begin{array}{l}\text { - Identifying potential local resources } \\
\text { and environmental resources that can } \\
\text { be developed into ecopreneur } \\
\text { products } \\
\text { - Developing designs into ecopreneur } \\
\text { products }\end{array}$ & $\begin{array}{l}\text { - Making product } \\
\text { - Developing student } \\
\text { creativity }\end{array}$ \\
\hline Product exhibition & $\begin{array}{l}\text { - Product assessment } \\
\text { - Promoting products by } \\
\text { presentations, socialization, or in } \\
\text { student ecopreneur exhibitions }\end{array}$ & $\begin{array}{l}\text { Cultivating } \\
\text { entrepreneurial interest } \\
\text { and spirit }\end{array}$ \\
\hline
\end{tabular}

In the concept formation and concept integration phases, a concept material module and an ecopreneur book, which contains basic entrepreneurial concepts, the inspiration for ecopreneur products, and motivation to become an Ecopreneur, are provided. Based on the learning observation results, the average active participation in three meetings is $77 \%$, meaning that most students are actively involved during the learning process and the making of ecopreneur products based on local resources.

\section{Student Entrepreneurial Interest through Ecopreneurship Learning}

The level of student entrepreneurial interest is measured by an entrepreneurial interest questionnaire given before and after learning. This is to find out the changes in the student interest before and after learning. A recapitulation of student entrepreneurial interest is presented in Table 2. 
Table 1. Student Entreprenurial Interest

\begin{tabular}{lcc}
\hline \multicolumn{1}{c}{ Data } & Pre & Post \\
\hline Student & 30 & 30 \\
Minimum & 53 & 56 \\
Maximum & 82 & 93 \\
Mean & 69 & 72 \\
Category & High & High \\
t-test & & 0.000 \\
\hline
\end{tabular}

Table 2 shows that SMA Prakarya students already have a high entrepreneurial interest as seen in the average percentage of student entrepreneurial interest questionnaires at the beginning of learning of $69 \%$ that increases to $72 \%$ (high category) after implementing ecopreneurship-based learning with local resources. Then, the distribution of student entrepreneurial interest data can be seen in Figure 1.

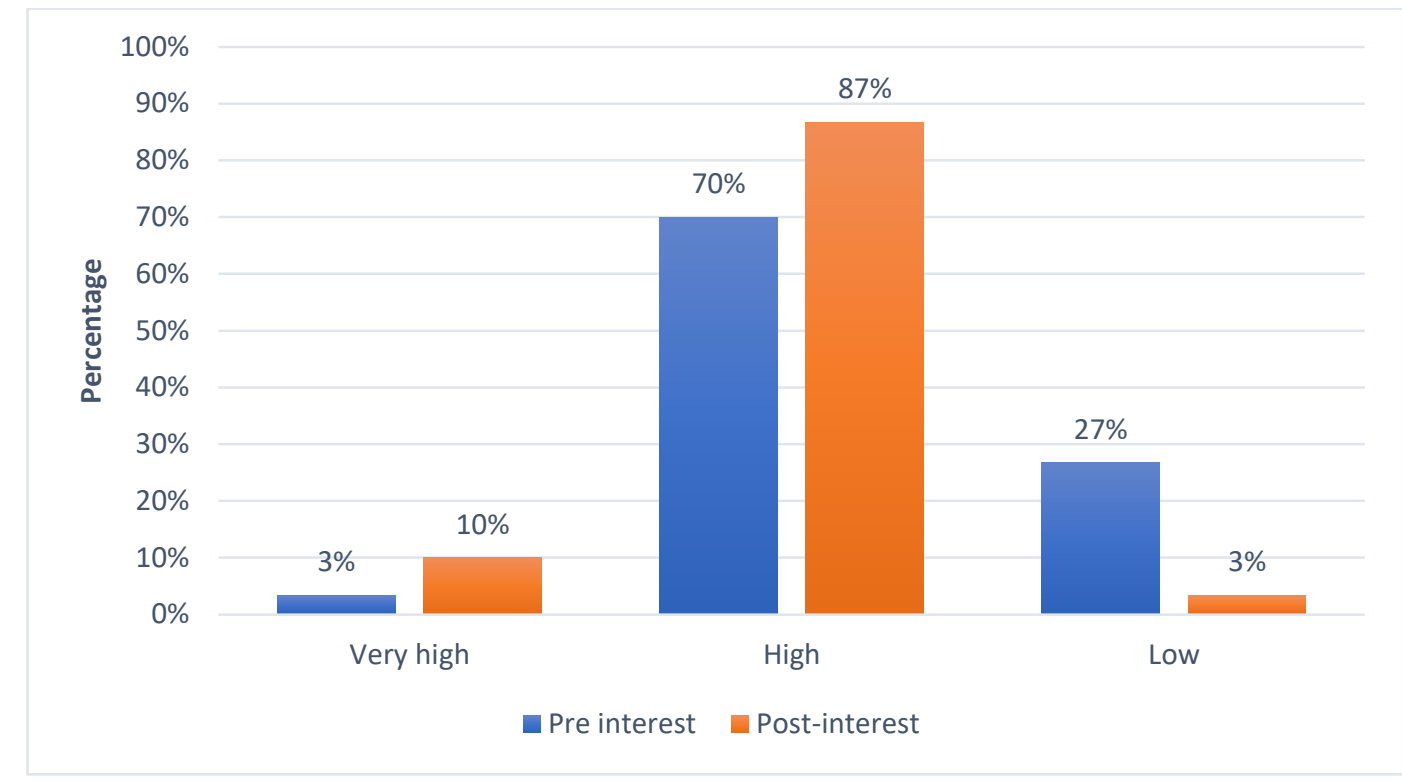

Figure 2. Category of entrepreneurial interest

Based on Figure 2, it is known that the low category of student entrepreneurial interest at the beginning of learning is $27 \%$ and, after learning, it decreases to only $3 \%$ or $24 \%$. The students change the perception of entrepreneurial interest. The results of statistical testing between initial and final interest in students also show a significant difference, which means that there is a change in student interest before and after learning. Thus, the learning process gives a positive impression, influencing student interest. The high interest is in line with the following products made by the students.

Figure 3 indicates that the ecopreneur products developed by the students are made of various local resources such as banana cake made of kepok bananas which are widely grown in Maja District. This type of banana has been consumed directly and has not been processed further. Siwang is made of shallots that are widely cultivated in Kulur and Maja Villages, and other crafts are also made of local resources around the school by transforming used goods into useful items. 
This ecopreneurship-based learning trains students to develop their creativity, life skills, and career as demanded by $21^{\text {st }}$-century learning where students must have the skills to develop projects and create a product (Trilling, B and Fadel, 2009). Ecopreneurship biology learning with local resources is in line with the vision of $21^{\text {st }}$-century education which requires students to be actively involved in learning and develop career skills to compete.

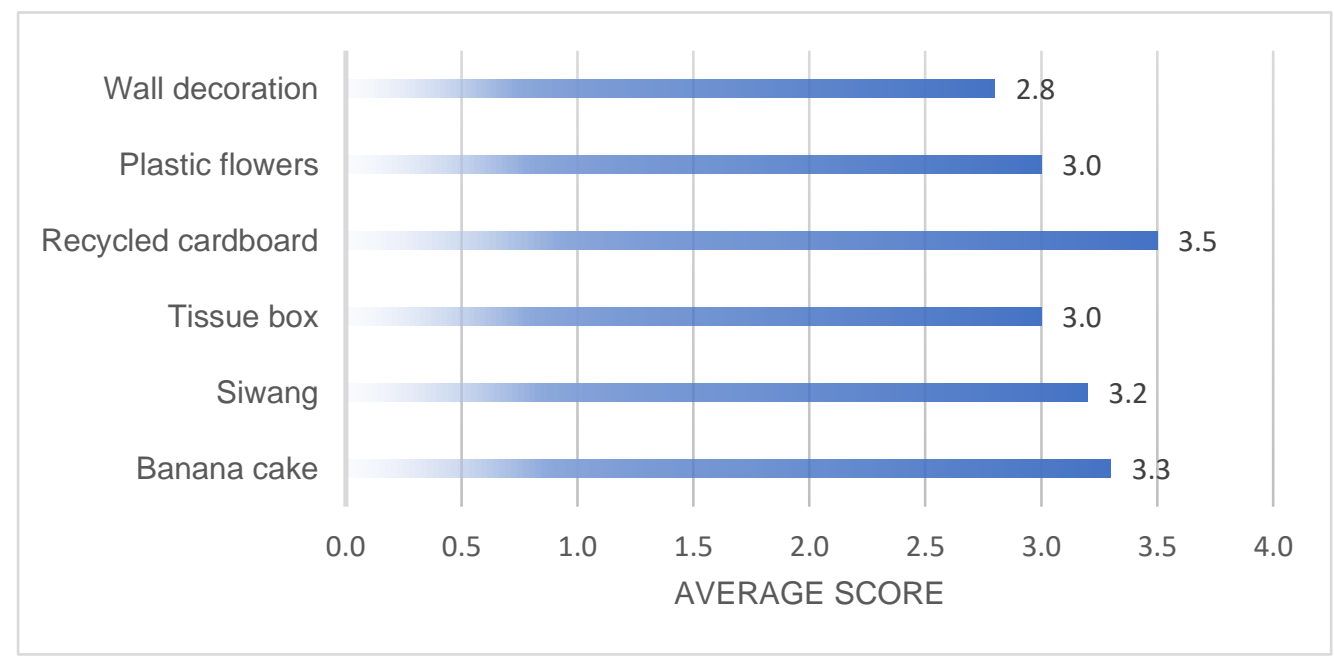

Figure 3. Assessment of Student Ecopreneur Product

A study found that rural communities in Cameroon respond positively to the ecological entrepreneur program, but it is difficult to implement ecopreneurship to maintain the sustainability of resources as raw materials (Mbebeb, 2012). Ecopreneurship biology learning can be implemented in appropriate learning materials to develop ecopreneurship in students through project-based learning.

Learning that integrates business concepts with education for sustainable development is in line with the vision of realizing a green economy which emphasizes the efficient use of environmentally-friendly natural resources (UNEP, 2011). This concept can be implemented early through entrepreneurship education based on ecopreneurship. The concept of ecopreneurshipbased learning in this study has been shown to have a positive effect on student ecopreneurial interest with an increase of $9.58 \%$. This concept can be a solution for sustainable development through large-scale ecopreneurship development and can be implemented early on through education (Astad, 1998).

\section{CONCLUSION}

The findings of this study, it can be summed up that ecopreneurship biology learning with local resources can improve student life skills and entrepreneurial interest. Ecopreneurship can be integrated into biology learning to provide students with life skills and careers as demanded by biology learning in the $21^{\text {st }}$ century

\section{ACKNOWLEDGMENT}

The author would like to thank the Ministry of Research and Technology-National Agency for Research and Technology for funding this research through a competitive novice lecturer research 
(PDP) grant scheme, as well as all parties who have helped during the research, especially the academic community of the Biology Education Study Program, Faculty of Teacher Training and Education, Universitas Majalengka and the principal, teachers, and students at Prakarya High School.

\section{REFERENCES}

Astad, P. (1998). Grassroots ecopreneurs: change agents for a sustainable society. Journal of Organizational Change Management, 11(2), 157. http://escweb.lib.cbs.dk/login?url=http://search.ebscohost.com/login.aspx?direct=true $\& \mathrm{db}=$ bth $\& A N$ $=3994317 \&$ site $=$ ehost-live

Beveridge, R., \& Guy, S. (2005). The rise of the eco-preneur and the messy world of environmental innovation. Local Environment, 10(6), 665-676. https://doi.org/10.1080/13549830500321972

Fitriah, E. (2012). Implementasi Bioentrepreneurship Pada Pembelajaran Biologi Untuk Meningkatkan Life Skills dan Minat Wirausaha Madrasah Aliyah Berbasis Pesantren di Cirebon. Scientia Educatiae, 1-19. file:///C:/Users/youhe/Downloads/kdoc_o_00042_01.pdf

Galkina, T., \& Hultman, M. (2016). Ecopreneurship - Assessing the field and outlining the research potential. Small Enterprise Research, 23(1), 58-72. https://doi.org/10.1080/13215906.2016.1188716

Holcombe, R. G. (1999). Entrepreneurship and Economic Growth: Reply. Quarterly Journal of Austrian Economics, 2(2), 73-78.

Isaak, R. G. L. (2002). Ecopreneurship, Theory and Ethics. Greenleaf Publishing.

Kirkwood, J., \& Walton, S. (2010). What motivates ecopreneurs to start businesses? International Journal of Entrepreneurial Behaviour and Research, 16(3), 204-228. https://doi.org/10.1108/13552551011042799

Martini, Rosdiana, L., Subekti, H., \& Setiawan, B. (2018). Strengthening students' characters and ecopreneurship through science, environment, technology, and society course. Jurnal Pendidikan IPA Indonesia, 7(2), 162-171. https://doi.org/10.15294/jpii.v7i2.14338

Mbebeb, F. E. (2012). Building Ecological Entrepreneurship: Creating Environmental Solutions Based on the Cultural Realities and Needs of Local People. 2(2), 43-62. file:///C:/Users/youhe/Downloads/kdoc_o_00042_01.pdf

McEwen, T. (2013). Ecopreneurship as a Solution to Environmental Problems: Implications for College Level Entrepreneurship Education. International Journal of Academic Research in Business and Social Sciences, 3(5), 264-288.

Santini, C. (2017). Ecopreneurship and Ecopreneurs: Limits, trends and characteristics. Sustainability (Switzerland), 9(4). https://doi.org/10.3390/su9040492

Solaja, O. M. (2017). Ecopreneurship and Green Product Initiative (GPI): An Agenda for Nigeria's Sustainable Development in the 21st Century. Studia i Materiaty Wydziatu Zarzadzania UW, 1/2017(23), 103-118. https://doi.org/10.7172/1733-9758.2017.23.10

Suryaningsih, Y., \& Aripin, I. (2020). Ecopreneurship Memanfaatkan Sumber Daya Lokal untuk Meningkatkan Minat Wirausaha dan Literasi Lingkungan. J. Pedagogi Hayati, 4(2).

Trilling, B and Fadel, C. (2009). 21st Century Skills, Learning For Life in Our Time. Jossey-Bass. 
UNEP. (2011). Pathways to Sustainable Development and Poverty Eradication - A Synthesis for Policy Makers. Towards a GREEN Economy, 52.

Widiasworo, E. (2017). Inovasi Pembelajaran Berbasis Life Skill dan Entrepreneurship. Ar Ruzz Media. 